\title{
The effects of turnout date to pasture on cattle weight gain
}

\author{
V. O. Nams ${ }^{1}$ and R. C. Martin ${ }^{2}$ \\ ${ }^{1}$ Department of Environmental Sciences, Nova Scotia Agricultural College, Box 550, Truro, Nova Scotia, Canada \\ B2N $5 E 3$ (email: vnams@nsac.ca); ${ }^{2}$ Department of Plant and Animal Sciences, Nova Scotia Agricultural College, \\ Box 550, Truro, Nova Scotia, Canada B2N 5E3. Received 21 December 2006, accepted 30 July 2007.
}

Nams, V. O. and Martin, R. C. 2007. The effects of turnout date to pasture on cattle weight gain. Can. J. Anim. Sci. 87: 527-534. The effects of multiple turnout dates on cattle weight gain were assessed in Nova Scotia in 1999 and 2000. Steers and heifers were released into pasture every 1 to $3 \mathrm{~d}$ from May 06 to May 28 in 1999 and from Apr. 26 to Jun. 05 in 2000 . Cattle turned out to pasture later in the season gained less weight. Turnout date had a similar effect in both years, and $1 \mathrm{~d}$ of earlier turnout increased weight by $0.789 \mathrm{~kg}$ per animal over the summer. The time for cattle weight to recover after entering the pasture did not vary with turnout date, but it did differ significantly between years, with cattle recovering weight faster in 2000 than in 1999 . Rate of weight gain decreased throughout the summer. The results suggest a mechanism for the turnout date effect: that cattle grow fastest on the pasture at the start of the season, and they grow faster on the pasture than in the barn. Thus, the earlier that they are introduced into the pasture, the more time they spend in the pasture during peak weight gain time. Rotational grazing maximizes the effect of turnout date by minimizing potential pasture degradation caused by early turnout.

Key words: Pasture, cattle, rotational grazing, recovery period, turnout date, weight gain

Nams, V. O. et Martin, R. C. 2007. Incidence de la date de mise à l'herbe sur le gain de poids des bovins. Can. J. Anim. Sci. 87: 527-534. Les auteurs ont évalué l'effet de diverses dates de mise à l'herbe sur l'engraissement des bpovins en NouvelleÉcosse. L'étude s'est déroulée en 1999 et 2000. Des bouvillons et des génisses ont été lâchés au pâturage du 6 au 28 mai en 1999 et du 26 avril au 5 juin en 2000. Les animaux mis à l'herbe plus tard dans la saison gagnent moins de poids. La date de mise à l'herbe a eu une incidence analogue les deux années, chaque journée de paissance supplémentaire se traduisant par une augmentation de poids de $0,789 \mathrm{~kg}$ par animal durant l'été. Le temps que les bovins prennent pour récupérer leur poids une fois au pâturage ne varie pas avec la date de mise à l'herbe, mais il diffère sensiblement d'une année à l'autre, les animaux ayant retrouvé leur poids plus rapidement en 2000 qu'en 1999. Le taux de gain de poids diminue tout au long de l'été. Ces résultats permettent d'avancer l'explication suivante pour l'incidence de la mise à l'herbe : les animaux engraissent plus vite quand ils paissent au début de la saison et croissent plus rapidement au pâturage qu'à l'étable. Par conséquent, plus tôt on les met à l'herbe, plus de temps ils demeurent au pâturage pendant la période la plus productive. Les pâturages tournants maximisent les effets de la date de mise à l'herbe en réduisant au minimum les risques de détérioration de la prairie attribuables à une paissance hâtive.

Mots clés: Paissance, bovins, pâturages tournants, période de récupération, date de mise à l'herbe, gain de poids

Beef cattle producers in the Atlantic provinces often graze their cattle on pasture from mid-May to October. Native pastures typically grow very rapidly in early spring with forage growth slowing as the season progresses (Boyd et al. 2001). Cattle are often placed on pasture when forage availability exceeds requirements and on an area large enough to support them until the fall when forage growth slows and animal consumption has increased. Consequently, forage production often exceeds cattle consumption in early spring. Earlier turnout to pasture may provide a partial solution to the problem (Jannasch et al. 2002).

Early turnout causes conflicting effects on weight gain. It may decrease weight gain by inefficient grazing in short swards. When grazing short swards animals compensate for the small bite size with increased travel and grazing time (Chacon et al. 1978). Cattle grazing short swards often lose weight because they are either unable to obtain sufficient dry matter intake or expend increased energy to obtain the sufficient dry matter (Charmley and Boyd 1997). On the other hand, early turnout may increase weight gain by delaying forage senescence. More severe early grazing in a rotationally grazed system increases the leaf:stem biomass ratio (Carton et al. 1989a) and reduces senescence rates (Carton et al. 1989b).

There are further confounding factors affecting the effect of turnout date. One is that cattle typically lose weight during the transition from confinement to pasture. This weight loss is often attributed to grazing efficiency, forage quality, or inadequate forage intake (Chacon et al. 1978; Charmley et al. 2003). Even when adequate forage is available cattle may lose weight for a brief period following turnout due to the time required for animals to adapt from confinement feeding to grazing (Charmley and Boyd 1997).

Abbreviations: ADF, acid detergent fiber; CP, crude protein; NDF, neutral detergent fiber 
Two other confounding factors are animal weight and age. Cattle that are younger and weigh less at turnout gain weight faster than animals put on pasture at a heavier weight (Yarrow et al. 1996). The proportion of fat deposition to the overall weight gain increases with animal maturity. Since fat is higher in caloric value, the efficiency with which dietary energy is used for body weight gain declines. This partially explains the decline in the average daily gain often seen in cattle as the grazing season progresses.

These many factors have resulted in studies finding contradictory effects of turnout date on weight gain. For example, Charmley et al. (2003) and Jannasch et al. (2002) found that earlier turnout date decreased weight gain, while Steen (2002) found the opposite. In order to resolve these contradictions it is important to elucidate the mechanism of the effect of turnout date. Past studies have found this difficult because they only tested two turnout dates and weighed cattle a small number of times. Our objectives were to find out by what mechanism turnout date affects weight gain of beef cattle in a rotationally grazed system. We tested a wide range of many turnout dates, and weighed cattle frequently during the summer.

\section{MATERIALS AND Methods}

\section{Study Site Description}

The study was conducted in 1999 and 2000 at the Nova Scotia Agriculture College in Truro, Nova Scotia, Canada $\left(45^{\circ} 14^{\prime} \mathrm{N}, 63^{\circ} 19^{\prime} \mathrm{W}\right)$. The pasture was predominately composed of Kentucky bluegrass (Poa pratensis L.), meadow fescue (Festuca pratensis Huds.), meadow foxtail (Alopecurus pratensis L.), and common white clover (Trifolium repens L.) grown on a Woodville Sandy loam soil (orthic humo-ferric podzol).

\section{Experimental Design}

Sixty Limousin crossbred steer and heifer feeder cattle were used each year of the experiment. Cattle were initially weighed in the barn on May 04 and Apr.19 in 1999 and 2000, respectively. Prior to turn out, the cattle were fed mixed grass silage [acid detergent fiber (ADF) 49\%] on a free choice basis and supplemented with 2 lbs barley per head per day. In addition, orts from dairy cow concentrate were offered on a free choice basis. One to four individuals were turned out to pasture every 1 to $3 \mathrm{~d}$ between May 06 and May 28 in 1999 and between Apr. 26 and Jun. 05 in 2000 (Table 1). Cattle were allocated to turnout groups in such a way as to minimize weight differences among groups at the start of the experiment. Each turnout group was treated as one sample in the analysis.

All cattle (both in the barn and pasture) were weighed whenever new cattle were introduced into the pasture. After all cattle were in the pasture, they were weighed twice per week till Jun. 11 in 1999 (after which they were weighed once a month), and twice per week till Sep. 18 in 2000. The frequent weighings allowed analysis of changes in rate of weight increase. The last weighing occurred on Aug. 17 in 1999 and Sep. 18 in 2000. All cattle were moved to a new paddock twice per week, with the area of paddock based on forage remaining in their current paddock and forage availability in the new paddock, as estimated by eye. Cattle were moved whenever new cattle were introduced, and all cattle had been introduced by the end of the first grazing cycle, thus, all new cattle entered ungrazed pasture. Although we did not specifically measure this, no bullying was noticed when the new cattle were introduced.

This experimental design was different from previous studies of cattle weight gain. Typically, cattle are grouped together for each treatment, and then are kept separate from other replicate groups. Increasing samples or treatments requires increasing the numbers of separate groups of cattle, and thus increases cost and effort. However, in our situation, the cattle were kept together as one herd on pasture; this ensured that the only difference among them was turnout time. This also gave a large sample size without the labor and cost of isolating each sample separately. Many turnout dates could be tested, increasing the power of statistical analyses to detect small effects, as well as separating out forage effects from cattle effects.

\section{Forage Measurements}

Forage quality and quantity were assessed in 2000 only. Biomass was harvested two times per week before cattle entered a paddock by clipping a $0.25-\mathrm{m}^{2}$ quadrat from the centre of each of 30 equally-sized blocks in the paddock. Forage heights were measured with a meter stick in each corner of each quadrat, and each corner of each block. Rising plate meter (Grasstec, Cork, Ireland) measurements were also taken in the center of each $0.25-\mathrm{m}^{2}$ quadrat before biomass sampling, as well as in 10 systematic equally placed locations in each block. The forage samples were oven-dried at $55^{\circ} \mathrm{C}$ for at least $48 \mathrm{~h}$ before weighing. Dried samples were analyzed for dry weight, acid detergent fiber (ADF), neutral detergent fiber (NDF) and crude protein (CP). ADF and NDF were determined using the procedures of Van Soest et al. (1991) and CP was determined by sample combustion using a Leco FP-228 analyzer (Leco Corp., St. Joseph, MI). Heat-stable amylase and sodium sulphite were used in the NDF procedure.

Dry weight and rising plate meter measurements were taken from the same quadrat before cattle entered the paddock, and rising plate meter measurements were taken after cattle left. Dry matter remaining after grazing was estimated using the regression of pre-grazing dry matter and rising plate meter measurements. Dry matter consumption was estimated by subtracting the estimated remaining dry matter after grazing from the available dry matter before grazing. This overestimated consumption when there was much trampling because of underestimated biomass.

\section{Statistical Methods}

The experimental design treated each group of 1-4 cattle with the same turnout date as one experimental unit. The general procedure for all analyses was to estimate various statistics for each turnout group, and then weight analyses by the number of cattle in each group. Since one statistic was estimated for each turnout group in each analysis, general linear model analyses were used. 


\begin{tabular}{|c|c|c|c|c|c|c|c|}
\hline \multicolumn{4}{|c|}{1999} & \multicolumn{4}{|c|}{2000} \\
\hline Turnout date & Mean weight (kg) & SD & $n$ & Turnout date & Mean weight $(\mathrm{kg})$ & $\mathrm{SD}$ & $n$ \\
\hline May 06 & 391 & 20 & 3 & April 26 & 333 & 55 & 3 \\
\hline 07 & 430 & - & 1 & 28 & 308 & 84 & 4 \\
\hline 08 & 377 & 7.1 & 2 & May 01 & 303 & 29 & 3 \\
\hline 10 & 424 & 14 & 2 & 03 & 312 & 51 & 3 \\
\hline 11 & 377 & 46 & 2 & 05 & 274 & 26 & 4 \\
\hline 12 & 380 & 0.7 & 2 & 08 & 351 & 27 & 2 \\
\hline 13 & 384 & 22 & 3 & 10 & 314 & 48 & 4 \\
\hline 14 & 379 & 9.5 & 3 & 12 & 297 & 39 & 4 \\
\hline 15 & 400 & 28 & 6 & 15 & 292 & 51 & 4 \\
\hline 17 & 409 & 34 & 3 & 17 & 331 & 51 & 3 \\
\hline 18 & 395 & 31 & 3 & 19 & 306 & 30 & 3 \\
\hline 19 & 406 & 30 & 3 & 22 & 306 & 46 & 3 \\
\hline 20 & 402 & 35 & 3 & 24 & 283 & 52 & 3 \\
\hline 21 & 394 & 16 & 3 & 26 & 318 & 41 & 4 \\
\hline 22 & 394 & 27 & 6 & 29 & 321 & 29 & 3 \\
\hline 24 & 389 & 6.7 & 2 & 31 & 280 & 33 & 3 \\
\hline 28 & 400 & - & 1 & June 02 & 318 & 29 & 3 \\
\hline 25 & 422 & 12 & 2 & 05 & 339 & 31 & 4 \\
\hline 28 & 383 & - & 1 & & & & \\
\hline 26 & 400 & 31 & 2 & & & & \\
\hline 28 & 402 & - & 1 & & & & \\
\hline 27 & 403 & 33 & 3 & & & & \\
\hline 28 & 400 & 27 & 3 & & & & \\
\hline
\end{tabular}

Total weight gain per animal was calculated from the time that the first cattle were introduced into the pasture until the first ones were removed from the pasture in late summer. Total weight gain was analyzed by linear regression using a weighted general linear model, with independent variables of turnout date, year, and turnout date $\times$ year (Wilkinson et al. 1999).

In 2000, forage measurements were correlated with the rate of weight gain. The rate of weight gain was estimated for each individual animal as a function of time, by using a sliding window of $30 \mathrm{~d}$. Within that window, a regression of weight versus time estimated rate of weight gain. Forage measurements were averaged within that window. Then a correlation was estimated between rate of weight gain and the forage measurements. Correlations were then averaged for each turnout group, and a weighted (by the number of cattle in the turnout group) $t$-test was used to test for nonzero correlations. The trial was conducted in accordance with guidelines laid down by the Canadian Council on Animal Care (1993).

\section{RESULTS}

\section{Overall Weight Gain}

Total weight gain was significantly affected by turnout date $(P<0.001$, d.f. $=1,35$; Fig. 1$)$ and year $(P<0.001$, d.f. $=$ $1,35)$, but not by an interaction between turnout date and year $(P=0.47$, d.f. $=1,35)$. There was also no significant relationship between turnout date and initial weight (1999: $\left.r^{2}=0.04, P=0.36 ; 2000: r^{2}=0.001, P=0.75\right)$. Thus, cattle turned out later gained less weight, with a similar effect of turnout date in both years. One day of earlier turnout increased weight by $0.789 \mathrm{~kg}$ per animal over the summer.
Cattle gained more weight in 2000 than in $1999\left(94.5 \pm 4.2^{1}\right.$ vs. $55.5 \pm 4.0 \mathrm{~kg})$.

\section{8-day Weight Gain}

In order to compare the results to this study with those of some other studies, the weight gain during the first $28 \mathrm{~d}$ of entering the pasture was analyzed (Fig. 2). Weight gain was not significantly affected by turnout date $(P=0.97$, d.f. $=$ $1,36)$ nor initial weight $(P=0.91$, d.f. $=1,36)$, nor were there any significant interactions. 28-day weight gain only differed between years $(P<0.001$, d.f. $=1,36)$. Cattle gained more weight in 2000 than in 1999 (11.2 $\pm 5.1 \mathrm{vs}$. $29.2 \pm 6.5 \mathrm{~kg})$.

\section{Overall Pattern of Weight Change}

In order to examine the source of these differences in weight gain, changes in weight throughout the season were explored. There were the same patterns in weight change for all cattle (Fig. 3), and thus the weight data were divided into three segments and each was analyzed separately: barn, the recovery period when first turned out into the pasture, and the pasture. The recovery period was defined as the time required for individual animals to attain body weight equal to their weight at turnout.

A linear regression of weight vs. date was used to estimate the rate of weight gain for each individual. This was done for the time while cattle were in the barn, and each month in the pasture. Then we averaged the growth rates over all individuals in each turnout group.

\footnotetext{
${ }^{1} \mathrm{All} \pm$ are $95 \%$ confidence intervals.
} 


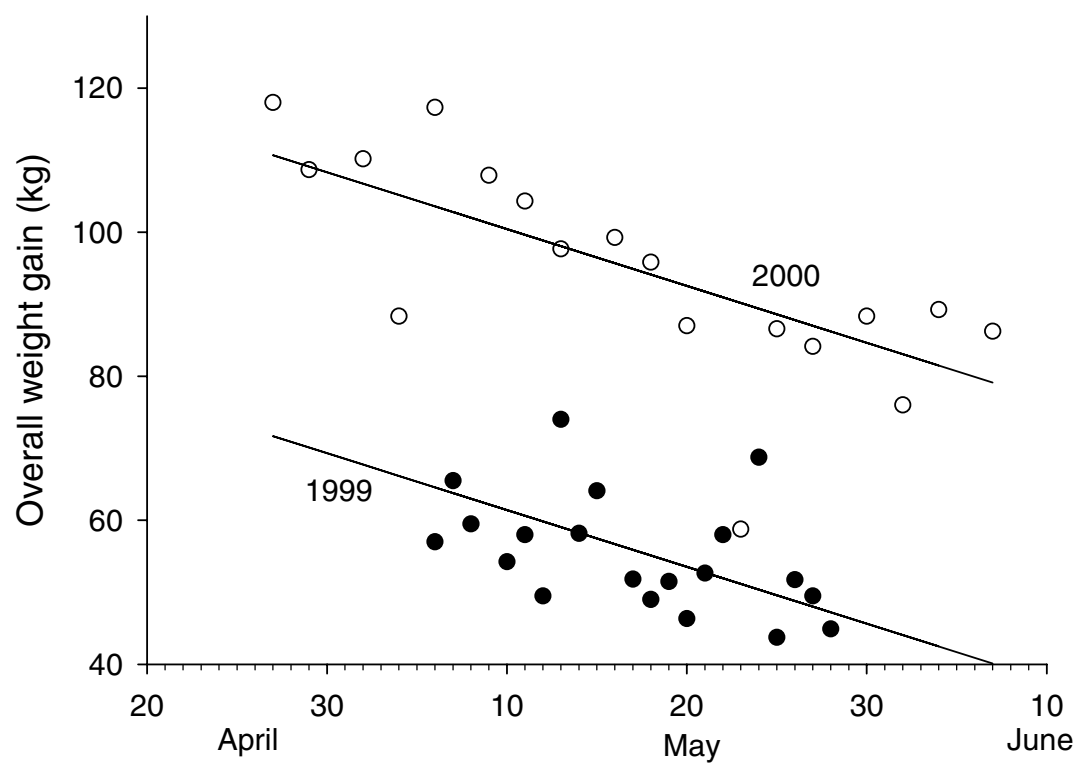

Turnout Date

Fig. 1. Overall weight gain vs. turnout date during 1999 and 2000. Each data point is the mean weight gain of all cattle turned out on that date. Open circles are 2000 and closed circles are 1999. Weight gain was calculated from the time that the first individual was introduced to the pasture, till Aug. 19. Cattle gained less weight when turned out later.

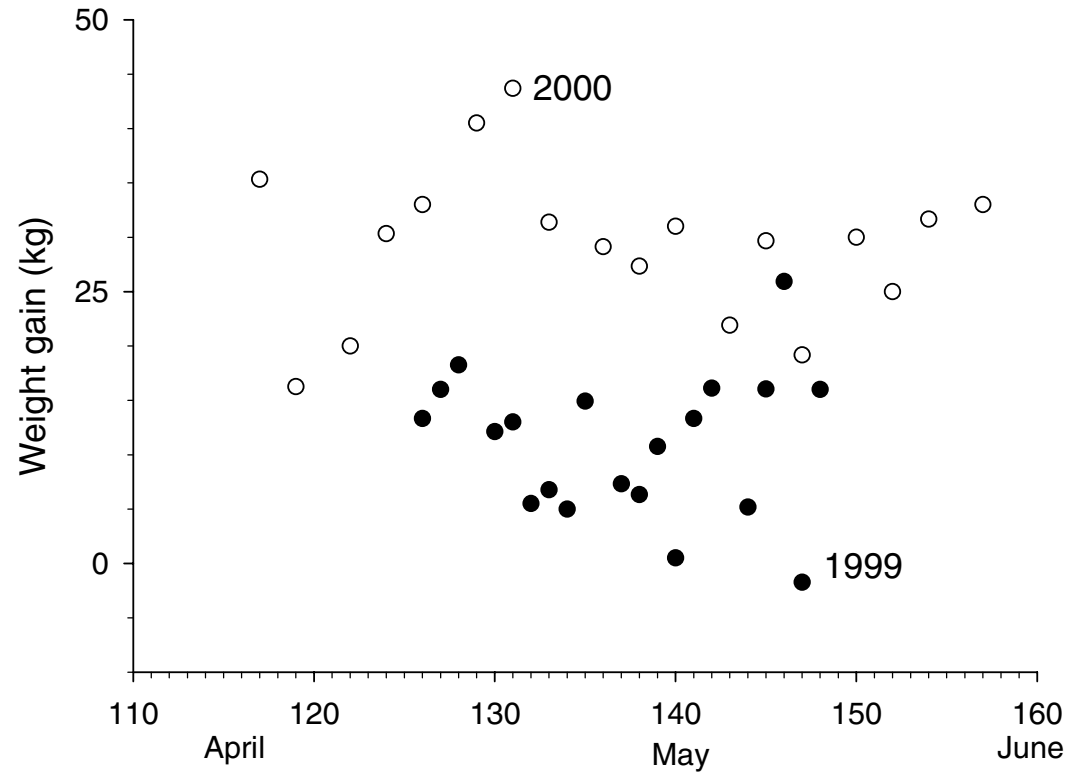

Days since turned out in pasture

Fig. 2. Weight gain over a 28-d period after first turned out to pasture. Each data point is the mean of all cattle turned out on that date. Open circles are 2000 and closed circles are 1999. There was no significant effect of turnout date. 


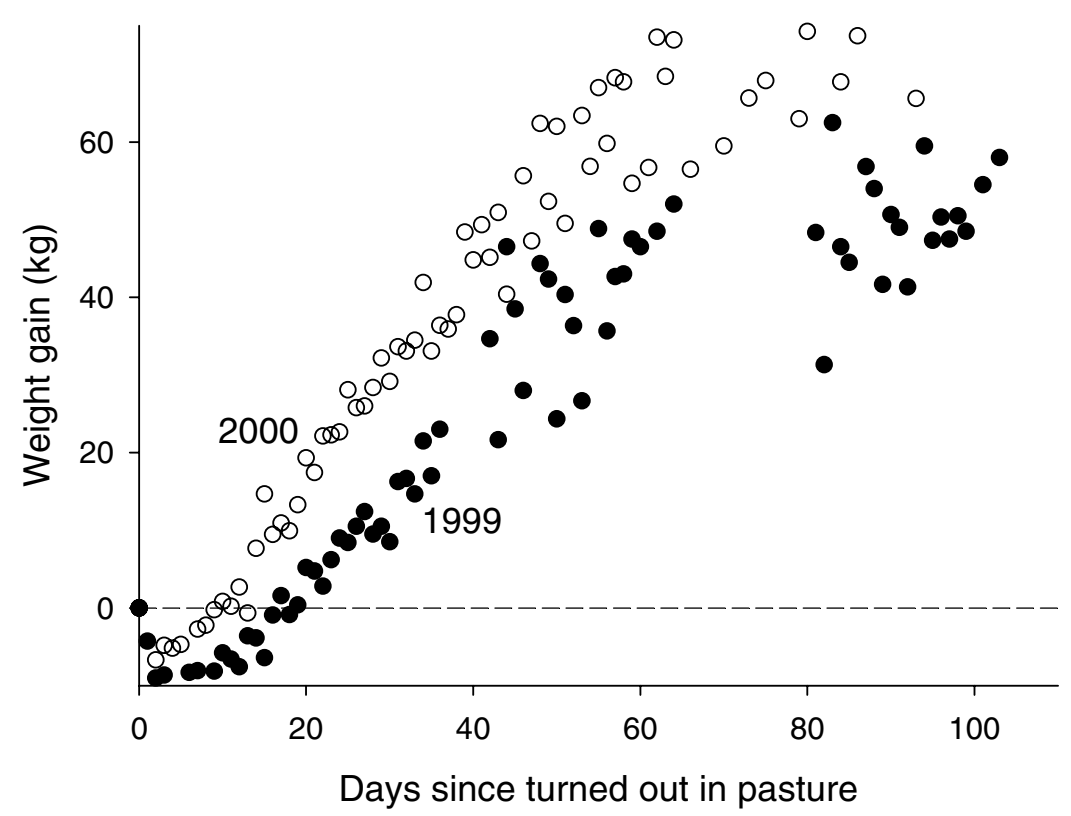

Fig. 3. Pasture weight gain for all cattle during 1999 and 2000. For each individual, weight zero is the weight at which it was turned out to the pasture. Open circles are 2000 and closed circles are 1999. Note the recovery period: the time for cattle weight to recover after introduction into the pasture.

\section{Recovery Period}

Length of the recovery period did not significantly vary with turnout date $(P=0.17, F=1.9$, d.f. $=1,34)$, but it did differ significantly between years $(P<0.001$, d.f. $=1,34)$. There was no significant interaction between turnout date and year $(P=0.85$, d.f. $=1,34)$. Cattle recovered weight faster in 2000 than in $1999(9.7 \pm 3.9$ vs. $18.4 \pm 4.9 \mathrm{~d})$.

\section{Rate of Weight Gain}

The mean rate of weight gain in the barn was $0.508 \pm 0.419$ $\mathrm{kg} \mathrm{d}^{-1}$ with no significant differences between years $(P=$ 0.79 , d.f. $=1,30)$, nor among turnout dates $(P=0.93$, d.f. $=$ $1,30)$, nor was there a significant interaction between turnout date and year $(P=0.77$, d.f. $=1,30)$.

While on pasture, rate of weight gain did not vary among turnout dates $(P=0.24$, d.f. $=1,30)$, nor among year and turnout date $(P=0.22$, d.f. $=1,30)$. However, there was a highly significant interaction between month and year $(P<$ 0.001 , d.f. $=3,30)$. Thus, weight gain differed among months and years. In both years, weight gain decreased throughout the summer, with a peak in May for 1999 and in June for 2000 (Fig. 4). Thus, once cattle were in the pasture, they gained weight at similar rates no matter when they were turned out. There was no significant effect of cattle weight on weight gain in $2000(P=0.45$, d.f. $=1,41)$, but there was in $1999(P<0.03$, d.f. $=1,39)$. However, in 1999 the effect of weight was positive, that is, heavier cattle gained weight faster than lighter cattle.

\section{Forage}

Forage quality changed throughout the season in year 2000 (Fig. 5). ADF increased but leveled off (quadratic regression vs. time: $\left.P=0.004, r^{2}=0.67\right)$. There was no significant change in NDF with time $\left(P=0.374, r^{2}=0.18\right)$. Crude protein content had a minimum value in early July (quadratic regression: $\left.P=0.001, r^{2}=0.73\right)$.

Forage quantity peaked in mid-summer. Total forage peaked at the end of June (quadratic regression: $P=0.004$, $\left.r^{2}=0.58\right)$, but there was no significant change in total CP $(P$ $\left.=0.19, r^{2}=0.19\right)$. Total forage available changed inversely with CP content (Fig. 6a vs. Fig. 5c), leading to no significant change in total $\mathrm{CP}$ with time (Fig. 6b). There were no significant changes in forage available per animal: neither in total biomass $\left(P=0.344, r^{2}=0.05\right)$ nor $\mathrm{CP}\left(P=0.19, r^{2}=\right.$ $0.14)$.

Most of the forage quality and quantity values correlated significantly with cattle growth rates, but many of the $r$-values were very small (Table 2). The largest significant correlation was with the amount of CP available per individual.

\section{DISCUSSION}

Cattle gained more weight overall when turned out earlier in the pasture, with a linear relationship between weight gain and turnout date. However, cattle gained weight at similar rates while in the barn, had similar recovery times, and once they were on the pasture, they gained weight at similar rates, irrespective of turnout date. These results are consistent over both years of our study, despite the great difference in weight gains between the two years.

Given these lack of differences, what is the mechanism of the turnout date effect? It has been suggested that this occurs because lighter cattle generally gain weight faster than heavier cattle on pasture (Yarrow et al. 1996), and that the impact of animal weight is often confounded with turnout date. 


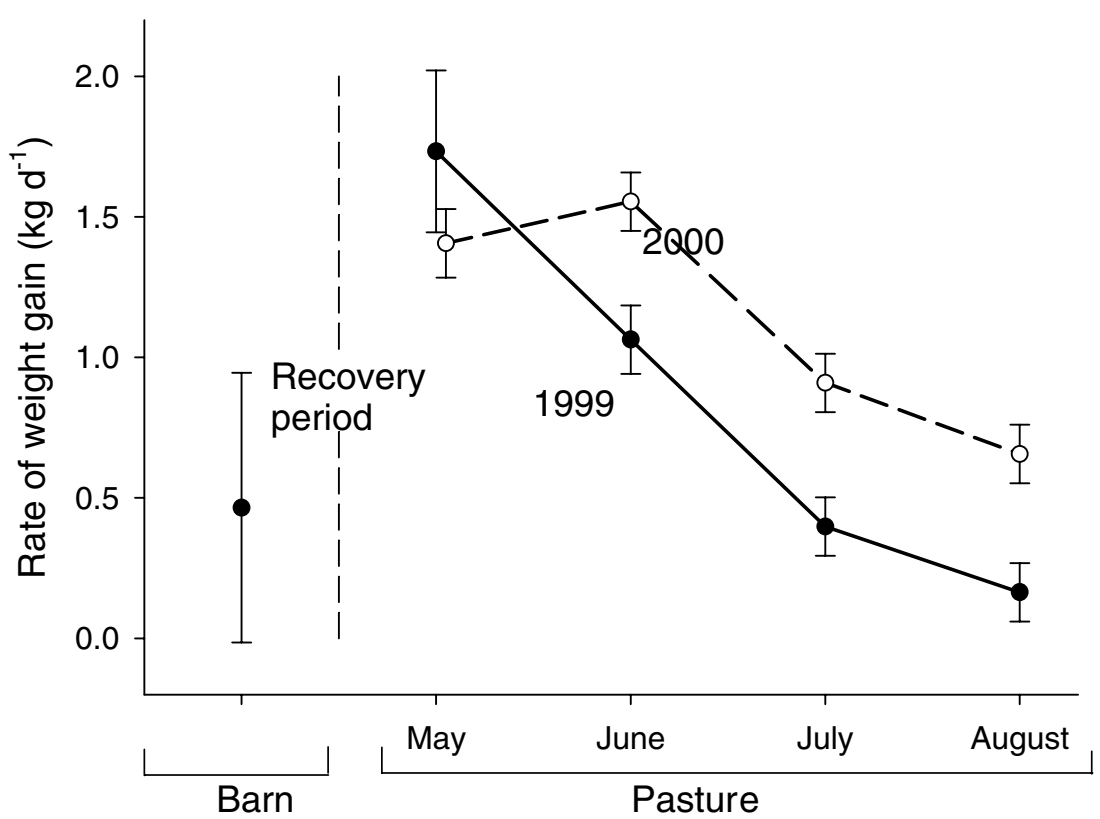

Fig. 4. Rate of weight gain for each month and year. Bars represent $95 \%$ confidence intervals. Open circles are 2000 and closed circles are 1999. Rate of weight gain decreased throughout the summer.

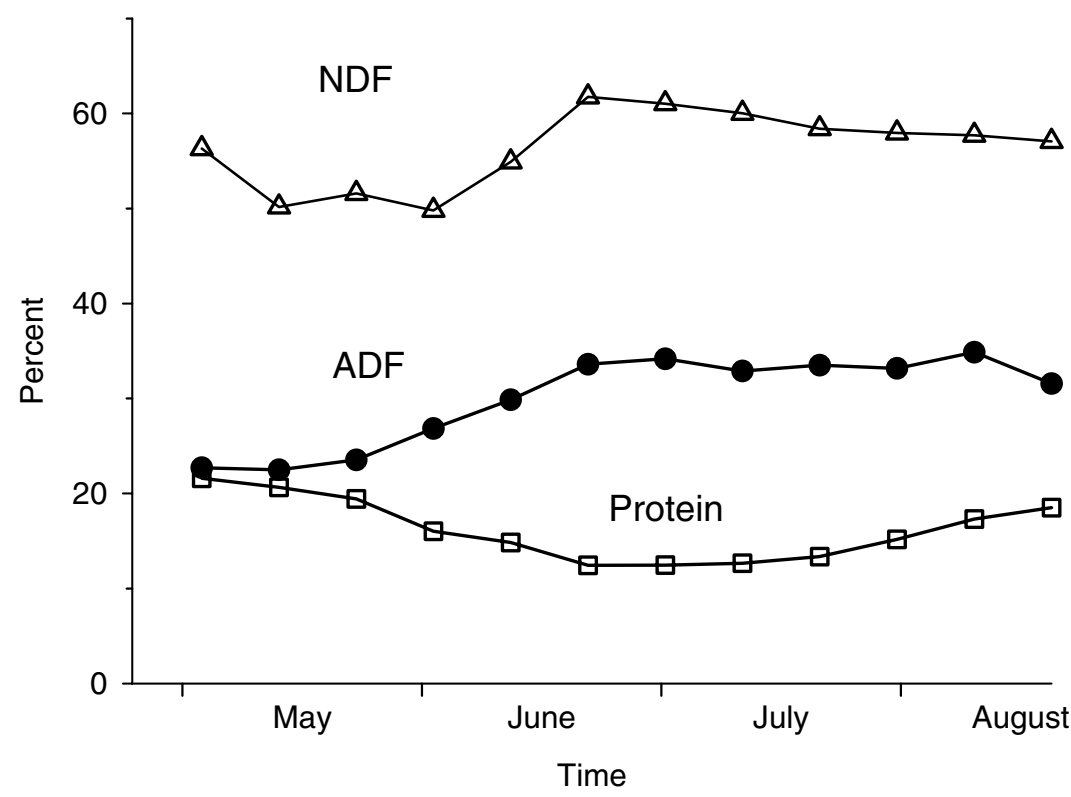

Fig. 5. Forage quality over the season in year 2000. ADF is acid detergent fiber and NDF is neutral detergent fiber.

However, this did not happen in our study because when average daily gain was examined on a monthly basis there was no significant interaction of turnout date with average daily gain.

It has also been suggested that this occurs because an earlier turnout date in a rotationally grazed system causes more severe grazing, leading to increases in the leaf:stem biomass ratio (Carton et al. 1989a) and reduced senescence rates (Carton et al. 1989b). However, this also did not happen in our study because all cattle were in the same pastures, and thus were fed the same forage.

We suggest that the mechanism of the turnout date effect is that cattle grow fastest on the pasture at the start of the season, and they grow faster on the pasture than in the barn (Fig. 4). Thus, the earlier that they are introduced into the pasture, the more time they spend in the pasture during peak weight gain time. 


\section{a) Total available}

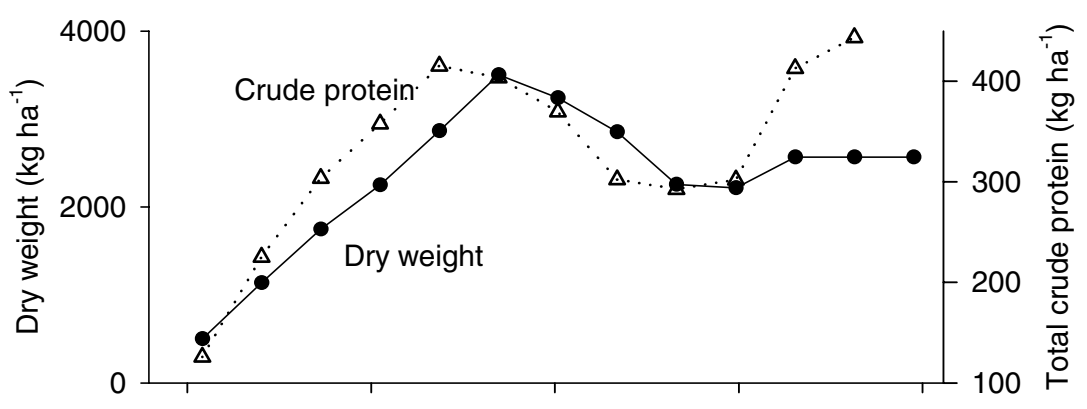

b) Amount available per animal

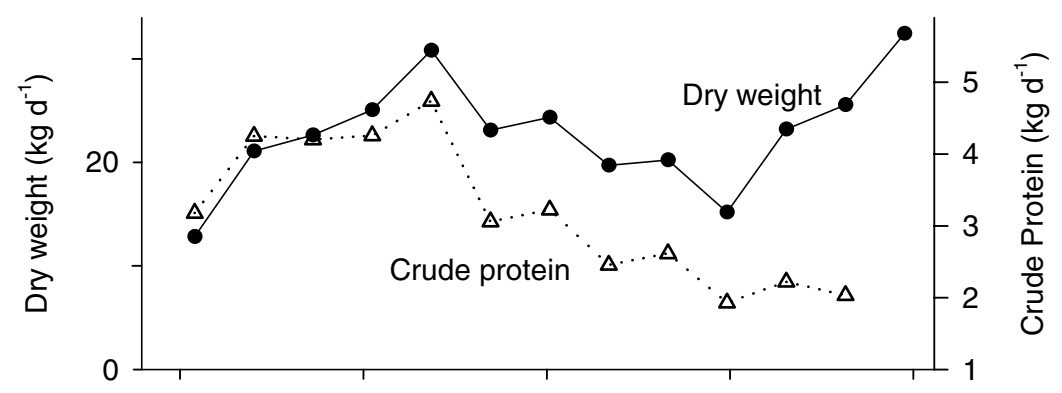

Fig. 6. Forage quantity available over the season in year 2000 .

Knowledge of this mechanism allows us to understand past contradictory results. Jannasch et al. (2002) found that earlier turnout date had inconsistent results - one year showed no significant effects, and one year showed cattle weight actually decreasing with earlier turnout date. Similarly, Charmley et al. (2003) found that earlier turnout date decreased weight gain. On the other hand, Steen (2002) found the opposite - that an earlier turnout date increased weight gain.

The cause of these differences is likely the timing of weight gain measurements. Jannasch et al. (2002) and Charmley et al. (2003) measured weight gain for a fixed period of time ( $28 \mathrm{~d}$ ) after entering pasture, while we and Steen (2002) measured weight gain at fixed dates. Using a fixed period of time removes the effects of differing amounts of time spent in the pasture vs. the barn, thus removing the cause of the turnout date effect. For example, when we analyze our data in that same way as did Jannasch et al. (2002) and Charmley et al. (2003), the effect of turnout date on weight gain disappears (Fig. 2). This is corroborated by Steen (2002) who also found that the turnout date effect disappears when comparing the same time period in the pasture.

\section{Weight Changes Throughout the Summer}

The decrease in weight gain throughout the summer magnified the effect of turnout date. The source of the turnout date effect is maximizing time spent on pasture when cattle are growing the fastest. Because weight gain decreases during

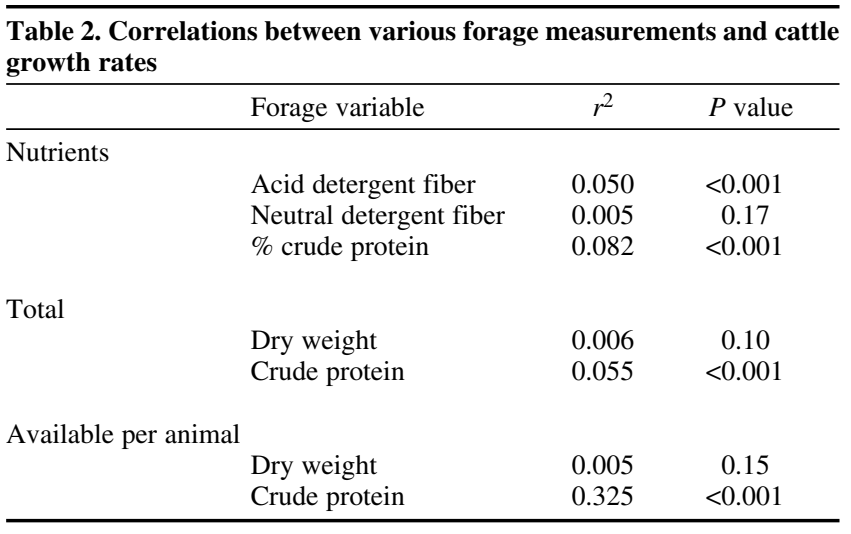

the summer, the greatest effect on cattle is early in the season. If weight gain stayed constant with time then the benefits of early turnout would be decreased, but would still exist. Thus, it is useful to understand why rate of weight gain decreased throughout the summer.

The decrease was not because of a change in weight of cattle; there was no significant effect of cattle weight on rate of weight gain in 2000, and an effect in the opposite direction in 1999. Thus there was no compensatory growth [as has been suggested by Moran and Holmes (1978)]. The decrease was also not because of stocking rates; while total biomass did decrease throughout the summer, the availability of those per animal increased during that time (Fig. 6). 
This decrease in rate of weight gain was likely due to a decrease in pasture quality. ADF increased and percentage CP decreased during May and June (Fig. 6).

This decrease in rate of weight gain was likely due to a decrease in pasture quality. ADF increased and percentage CP decreased during May and June (Fig. 5), and growth weight correlated with the amount of $\mathrm{CP}$ available per individual. It is also known that more severe early grazing in a rotationally grazed system increases the leaf:stem biomass ratio (Carton et al. 1989a) and reduces senescence rates (Carton et al. 1989b). Increasing our stocking rates may have minimized the decrease in pasture quality, although we cannot say how much of the decrease was because of grazing pressure vs. season.

\section{Rotational Grazing}

Using rotational grazing likely magnifies the benefits of early turnout for producers. The major potential problem with early turnout is degradation of pasture. Using rotational grazing allows producers to minimize pasture degradation in two ways: first, the pastures used early in the season are allowed to recover before being grazed again, and second, stocking density can be adjusted throughout the growing season to maximize pasture quality. However, while rotational grazing magnifies the benefits of early turnout, it is not required, since Steen (2002) used a fixed grazing system but still found that early turnout increases weight gain.

\section{Experimental Design}

Our experimental design allowed us to measure the turnout effect with high precision because of the many turnout dates. However, there are two limitations to this design. First, this design cannot be used in a fixed grazing system because the later cattle would be entering a pasture that had already been grazed. In our system of rotational grazing all cattle were moved to a new, non-grazed, section of pasture on the days that new cattle were introduced. Thus this design measures the effects of time and initial sward quality. Second, this design does not measure the effects of pasture degradation, since all cattle grazed the same pasture. However, this limitation is ameliorated since rotational grazing minimizes pasture degradation.

\section{Implications}

Early turnout should offer economic benefits to cattle producers in the Atlantic Provinces. When initially introduced into pasture all cattle lose weight for similar periods of time, irrespective of turnout dates. The recovery period is in effect forced "wasted time". Since cattle cannot gain weight during this time, they should be in the pasture early enough so that once the pasture is capable of supporting rates of weight gain greater than in the barn, cattle will have recovered and are ready to grow. This is especially true with rotationally grazed systems, where early pasture degradation is minimized. The time to do this in Atlantic Canada would be $\sim 10$ $\mathrm{d}$ before the anticipated "spring flush" of grass. More research is needed to predict when and how vigorous the "spring flush" will be. One day of earlier turnout can increase weight by $0.8 \mathrm{~kg}$ per animal over the summer.

\section{ACKNOWLEDGEMENTS}

This research was financed by a Natural Sciences and Engineering Research Council of Canada Strategic grant. We thank Rupert Jannasch, Kristene Taylor, and Nathan Boyd for field assistance, and Nathan Boyd for editorial assistance.

Boyd, N. S., Astatkie, T., Fredeen, A. H. and Martin, R. C. 2001. Rotationally stocked beef cattle responses to daily and weekly residence. J. Range. Manage. 54: 39-43.

Canadian Council on Animal Care 1993. Guide to the care and use of experimental animals Vol 1. CACC, Ottawa, ON.

Carton, O. T., Brereton, A. J., Okeeffe, W. F. and Keane, G. P. 1989a. Effect of turnout date and grazing severity in a rotationally-grazed reproductive sward: 1. Dry matter production. Irish J. Agric. Res. 28: 153-163.

Carton, O. T., Breton, A. J., Okeeffe, W. F. and Keane, G. P. 1989b. Effect of turnout date and grazing severity in a rotationally-grazed reproductive sward: 2 Tissue turnover. Irish J. Agric. Res. 28: 165-175.

Chacon, E. A., Stobbs, T. H. and Dale, M. B. 1978. Influence of sward characteristics on grazing behaviour and growth of Hereford steers grazing tropical grass pastures. Aust. J. Agric. Res. 29: 89-102.

Charmley, E. and Boyd, J. 1997. Factors influencing weight loss of steers upon turnout to pasture. Can. J. Anim. Sci. 77: 744-744. Charmley, E., Jannasch, R. W. and Boyd, J. 2003. Grazing behaviour and weight change of cattle turned out to pasture in spring. Can. J. Anim. Sci. 83 : 801-808.

Jannasch, R. W., Charmley, E. and Rodd, A. V. 2002. The effect of spring turnout date on weight gain by cattle on native pasture. Can. J. Anim. Sci. 82: 575-585.

Moran, J. B. and Holmes, W. 1978. The application of compensatory growth in grass/cereal beef production systems in the United Kingdom. World Rev. Anim. Prod. 14: 65-73.

Steen, R. W. J. 2002. Effects on performance and carcass composition of turning beef cattle out to pasture early in the spring. Grass Forage Sci. 57: 401-404.

Van Soest, P. J., Robertson, J. B. and Lewis, B. A. 1991. Methods for dietary fiber, neutral detergent fiber, and nonstarch polysaccharides in relation to animal nutrition. J. Dairy Sci. 74: 3583-3597.

Wilkinson, L., Hill, M.A., Welna, J.P. and Birkenbeuel, G.K. 1999. SYSTAT for Windows: Statistics, Version 9. SYSTAT Inc, Evanston, IL.

Yarrow, N. H., Penning, P. D. and Johnson, R. H. 1996. The effect of plane of winter nutrition and sward height on the performance of steers grazing grass/white clover swards. Grass Forage Sci. 51: 424-433. 